Key Words:

Saltstone

Hydraulic Conductivity

Permeameter

Retention: Permanent

\title{
Permeability Testing of Simulated Saltstone Core and Vault 4 Cell E Saltstone
}

Ralph L. Nichols

Kenneth L. Dixon

October 2010

Savannah River National Laboratory

Savannah River Nuclear Solutions

Aiken, SC

Prepared for the U.S. Department of Energy under

Contract Number DE-AC09-08SR22470

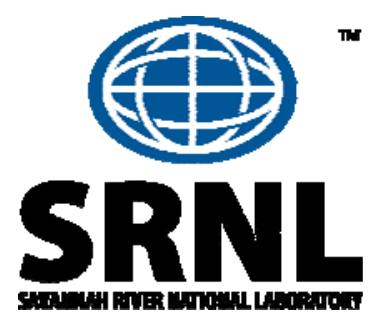




\section{DISCLAIMER}

This work was prepared under an agreement with and funded by the U.S. Government. Neither the U. S. Government or its employees, nor any of its contractors, subcontractors or their employees, makes any express or implied: 1. warranty or assumes any legal liability for the accuracy, completeness, or for the use or results of such use of any information, product, or process disclosed; or 2. representation that such use or results of such use would not infringe privately owned rights; or 3. endorsement or recommendation of any specifically identified commercial product, process, or service.

Any views and opinions of authors expressed in this work do not necessarily state or reflect those of the United States Government, or its contractors, or subcontractors.

Printed in the United States of America

Prepared for

U.S. Department of Energy 


\section{Table of Contents}

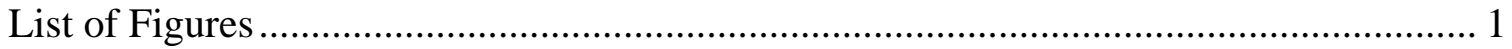

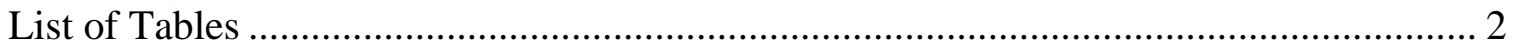

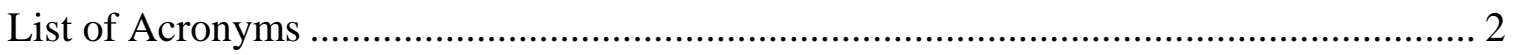

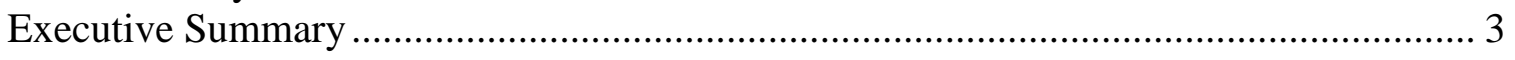

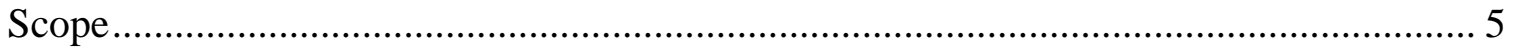

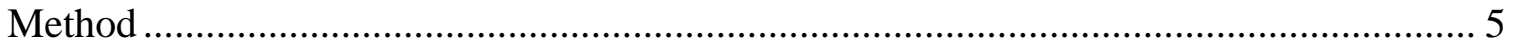

Simulated Saltstone Samples .......................................................................... 6

Radioactive Samples ..................................................................................... 7

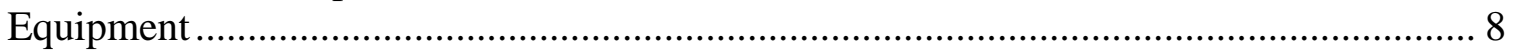

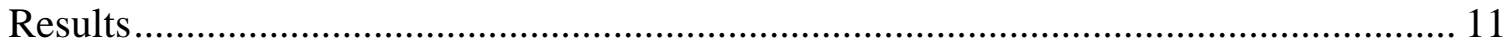

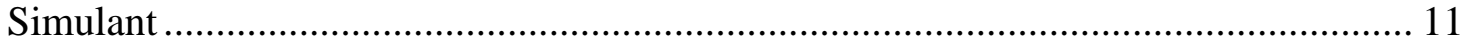

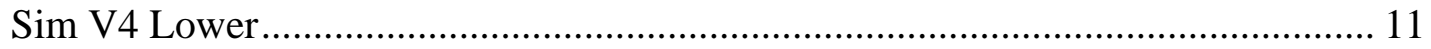

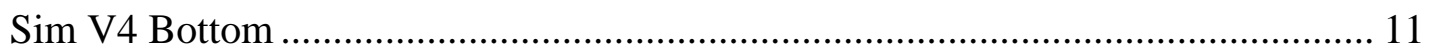

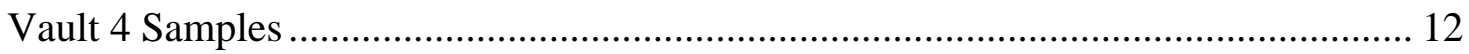

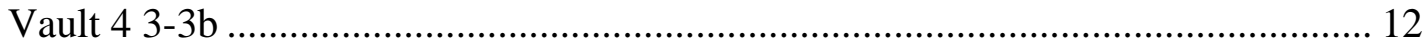

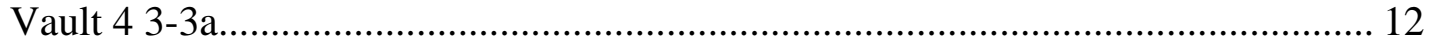

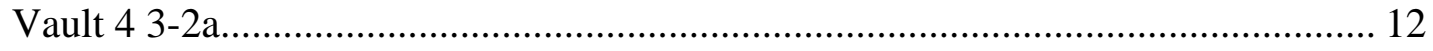

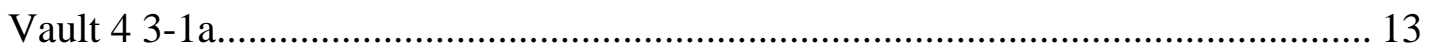

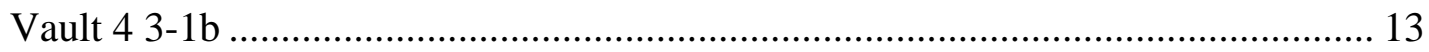

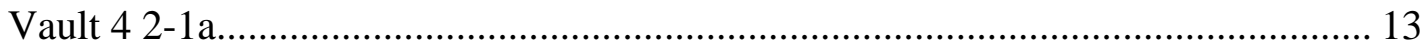

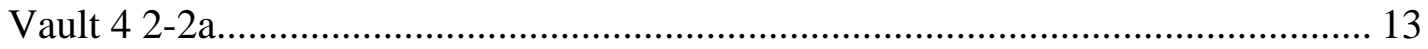

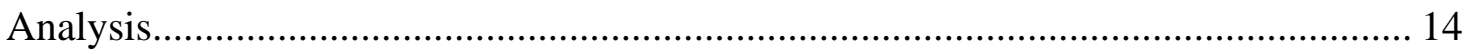

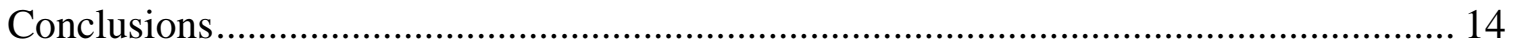

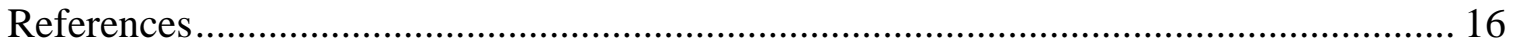

\section{List of Figures}

Figure 1 Drainage curve for simulated saltstone. .................................................... 6

Figure 2 Scanning electron micrograph of saltstone from Vault 4 Cell E......................... 6

Figure 3 Cored sample of simulated saltstone (a) bucket of cured simulated saltstone (b)

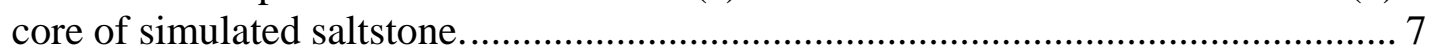

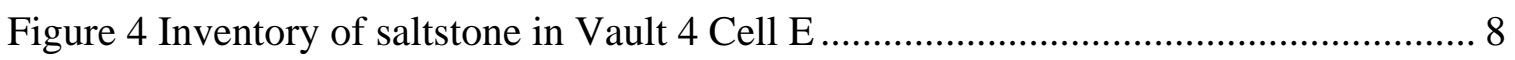

Figure 5 Saltstone sample in flexible wall permeameter............................................. 9

Figure 6 Photo of flexible wall permeameter with permeant interface devices. ............. 10 Figure 7 Hydraulic conductivity values for saltstone simulant and Vault 4 Cell samples. 


\section{List of Tables}

Table 1 Chemical composition of WCS 11302007 permeant. ............................................ 11

Table 2 WCS 11302007 permeant properties at $20^{\circ} \mathrm{C}$..................................................... 11

Table 3 Results from flexible wall permeameter testing of simulated saltstone samples. 15

\section{List of Acronyms}

$\begin{array}{ll}\text { EPD } & \text { Engineering Process Development } \\ \text { ERTS } & \text { Environmental Restoration Technology Section } \\ \text { FWP } & \text { Flexible wall permeameter } \\ \text { MCU } & \text { Modular Caustic Side Solvent Extraction Unit } \\ \text { PID } & \text { Permeant interface device } \\ \text { SDF } & \text { Saltstone Disposal Facility } \\ \text { SRNL } & \text { Savannah River National Laboratory } \\ \text { SS } & \text { Stainless steel } \\ \text { K } & \text { Hydraulic conductivity } \\ i & \text { Hydraulic gradient }\end{array}$




\section{Executive Summary}

The Engineering Process Development Group (EPD) of the Savannah River National Laboratory (SRNL) prepared simulated saltstone core samples to evaluate the effect of sample collection by coring on the permeability of saltstone. The Environmental Restoration Technology Section (ERTS) of the SRNL was given the task of measuring the permeability of cores of simulated saltstone. Saltstone samples collected from Vault 4 Cell E using both dry and wet coring methods were also submitted for permeability analysis. The cores from Vault 4 Cell E were in multiple pieces when they were recovered (Smith, 2008 Cheng et.al, 2009). Permeability testing was only performed on the portions of the core sample that were intact, had no visible fractures or cracks, and met the specifications for "undisturbed specimens" identified in Method ASTM D508403 Standard Test Methods for Measurement of Hydraulic Conductivity of Saturated Porous Materials Using a Flexible Wall Permeameter that was used for the testing.

Permeability values for cores of simulated saltstone compared with values from permeability tests conducted on molded saltstone samples by an independent laboratory using the same method. All hydraulic conductivity results for Vault 4 samples exceeded results for both molded and cored saltstone simulant samples. The average hydraulic conductivity result for Vault 4 Cell E samples of $3.9 \times 10^{-7} \mathrm{~cm} / \mathrm{sec}$ is approximately two orders of magnitude greater than that of the simulated saltstone with an average of $4.1 \mathrm{x}$ $10^{-9} \mathrm{~cm} / \mathrm{sec}$. Numerical flow and transport simulations of moisture movement through saltstone performed for the performance assessment of the Saltstone Disposal Facility (SDF) used $2.0 \times 10^{-9} \mathrm{~cm} / \mathrm{sec}$ for the hydraulic conductivity of saltstone (Flach et al, 2009). The results for simulated versus actual saltstone were further compared using non-parametric statistics. The results from non-parametric statistical analysis of results indicate that there is at least a $98 \%$ probability that the hydraulic conductivity of saltstone samples collected from Vault 4 Cell E saltstone is greater than that of the baseline simulant mix. 
Results from flexible wall permeameter testing of simulated saltstone samples and saltstone samples collected from Vault 4 Cell in the SDF are shown in below:

\begin{tabular}{|c|c|c|}
\hline Sample Id & $\begin{array}{c}\text { Hydraulic } \\
\text { Conductivity } \\
\text { (cm/sec) }\end{array}$ & $\begin{array}{c}\text { Intrinsic } \\
\text { Permeability } \\
\text { (Darcy) }\end{array}$ \\
\hline $\begin{array}{c}\text { Molded Simulated } \\
\text { Saltstone (a) }\end{array}$ & $\begin{array}{c}8.8 \times 10^{-10} \\
\text { to } \\
9.9 \times 10^{-9}\end{array}$ & $\begin{array}{c}1.8 \times 10^{-6} \\
\text { to } \\
2.0 \times 10^{-5}\end{array}$ \\
\hline Sim Cored V4 Lower & $3.5 \times 10^{-9}$ & $6.5 \times 10^{-6}$ \\
\hline Sim Cored V4 Bottom & $4.4 \times 10^{-9}$ & $8.2 \times 10^{-6}$ \\
\hline Vault 4 Cell E 3-1a & $1.9 \times 10^{-6}$ & $3.5 \times 10^{-3}$ \\
\hline Vault 4 Cell E 3-3b & $1.6 \times 10^{-8}$ & $2.9 \times 10^{-5}$ \\
\hline Vault 4 Cell E 3-3a & $2.1 \times 10^{-7}$ & $3.9 \times 10^{-4}$ \\
\hline Vault 4 Cell E 3-2a (b) & $2.6 \times 10^{-7}$ & $4.8 \times 10^{-4}$ \\
\hline Vault 4 Cell E 3-2a (c) & $2.6 \times 10^{-7}$ & $4.7 \times 10^{-4}$ \\
\hline Vault 4 Cell E 3-1b (d) & $1.5 \times 10^{-7}$ & $2.7 \times 10^{-4}$ \\
\hline Vault 4 Cell E 3-1b (e) & $1.4 \times 10^{-7}$ & $2.6 \times 10^{-4}$ \\
\hline Vault 4 Cell E 2-1a & $1.1 \times 10^{-7}$ & $1.9 \times 10^{-4}$ \\
\hline Vault 4 Cell E 2-2a & $9.9 \times 10^{-8}$ & $1.8 \times 10^{-4}$ \\
\hline Vault 4 Cell E 3-1a (f) & $8.8 \times 10^{-7}$ & $1.6 \times 10^{-4}$ \\
\hline
\end{tabular}
(a) Dixon et al, 2009
(b) Pore pressure $=40$ psig
(d) Hydraulic gradient $=13$
(e) Hydraulic gradient $=26$
(c) Pore pressure $=85$ psig
(f) Tested 73 days after initial test of 3-1a 


\section{Scope}

The Engineering Process Development Group (EPD) of the Savannah River National Laboratory (SRNL) prepared simulated saltstone core samples to evaluate the effect of sample collection by coring on the permeability of saltstone (Cozzi and Duncan, 2009). The Environmental Restoration Technology Section (ERTS) of the SRNL was given the task of measuring the permeability of cores of simulated saltstone. Saltstone samples collected from Vault 4 Cell E were also submitted for permeability analysis.

\section{Method}

Method ASTM D5084-03 Standard Test Methods for Measurement of Hydraulic Conductivity of Saturated Porous Materials Using a Flexible Wall Permeameter as described in Nichols and Dixon, 2009 was used for the permeability measurements. Specifically, Method C, Falling head/rising tailwater elevation of ASTM D5084-03 was selected for the saltstone samples. Method $C$ was chosen for use in measuring the hydraulic conductivity $(K)$ of saltstone samples due to their low $K$. The increased resolution in data collected using the falling head/rising tail apparatus justifies the additional equipment complexity when testing low $K$ materials. The test is conducted by measuring fluid flow through a porous material in response to an applied hydraulic gradient.

The core samples submitted by EPD were initially saturated with de-aired permeant in a vacuum chamber to evacuate air in the pore space and allow permeant penetration. The use of de-aired permeant reduces gas bubble formation that can result from degassing within the sample. The porous plates and glass fiber filters to be used with the sample are also saturated under a vacuum with de-aired permeant. Gas bubbles in the pore spaces of fine grained materials will invalidate the flexible wall permeameter (FWP) test resulting in underestimating $K$. Figure 1, the drainage curve and relative permeability curve for simulated saltstone, shows that relative permeability and thus hydraulic conductivity decreases by $\sim 1$ order of magnitude with a reduction of saturation from 1.0 to 0.8 . Likewise, small deviations from a saturation of 1.0 can have a large effect on test results producing artificially low values for $\mathrm{K}_{\text {sat }}$. Scanning electron microscopy of simulated saltstone, Figure 2, reveals the large variability in pore structure and size that contributes to the long drainage curve. 


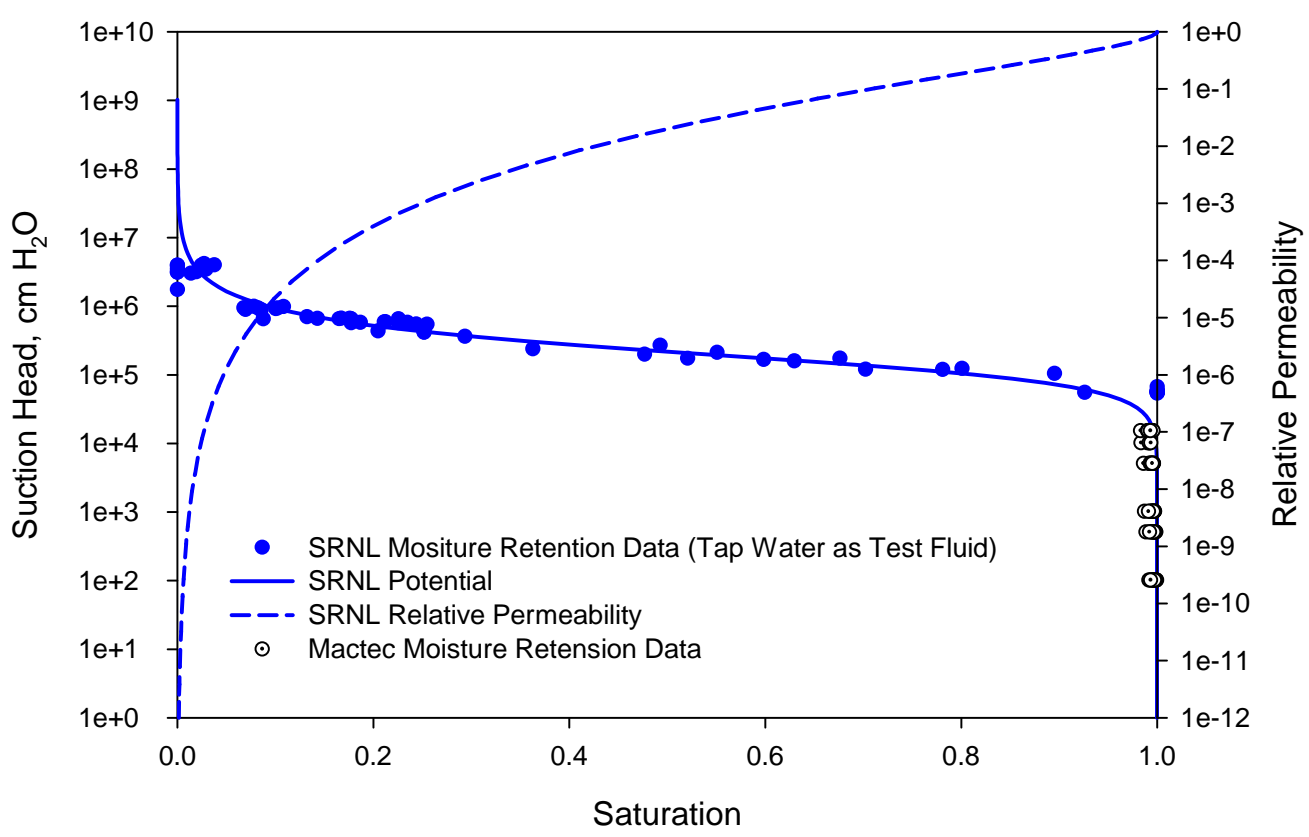

Figure 1 Drainage curve for simulated saltstone.
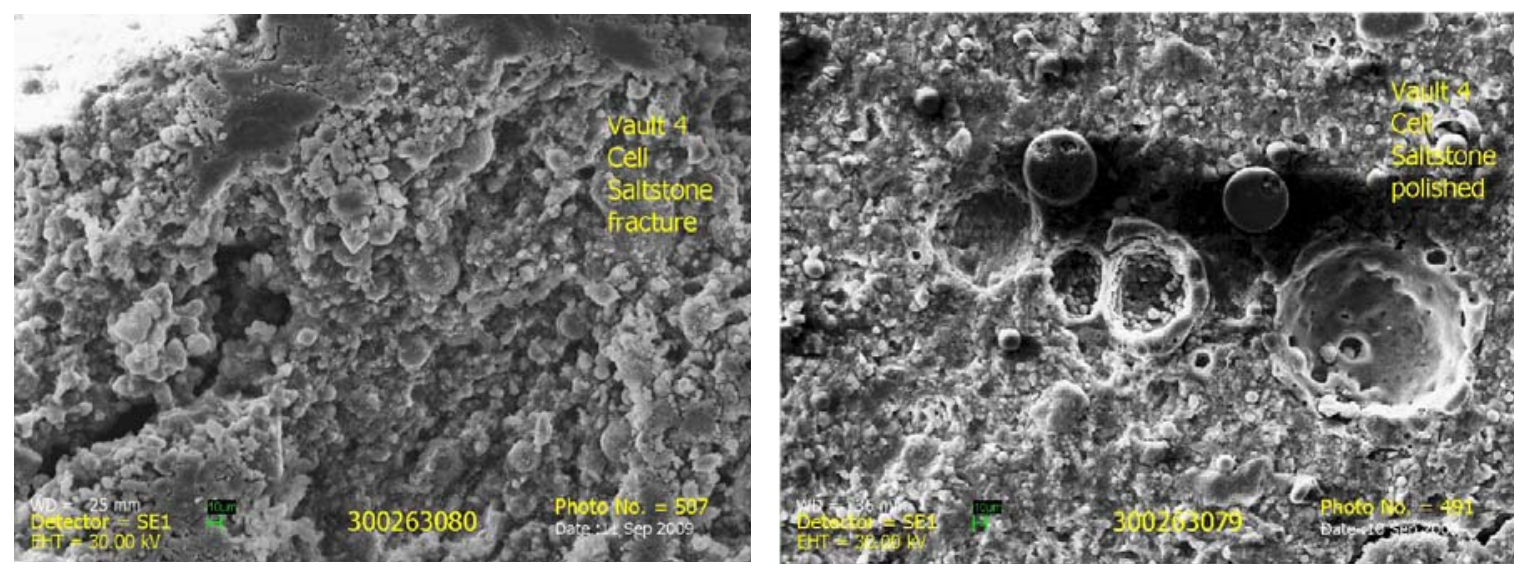

Figure 2 Scanning electron micrograph of saltstone from Vault 4 Cell E.

\section{Simulated Saltstone Samples}

The core samples were collected from a five gallon sample of simulated saltstone that had cured approximately 300 days (Appendix A). The simulated saltstone was prepared using the Saltstone Processing Facility (SPF) "baseline” mix, mix 2 of 11 in Harbor, 2008, without the set retarder and antifoam and cured at room temperature. Figure 3 shows the five gallon bucket of cored saltstone simulant and the resulting core (Cozzi and Duncan 2009). The core sample of simulant was collected using the same dry method used to collect core from location 1 and 3 in Vault 4 Cell E described in the next section 
of this report. This sample was prepared and tested to assess the effects coring may have on the sample.

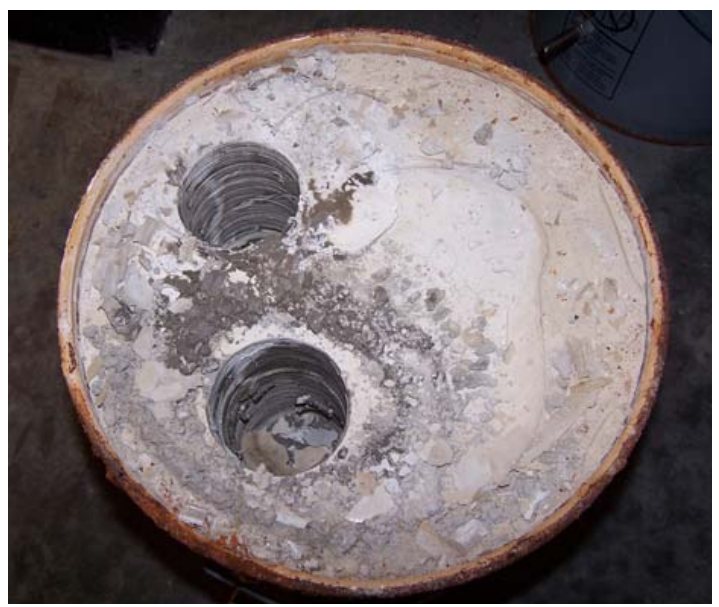

(a)

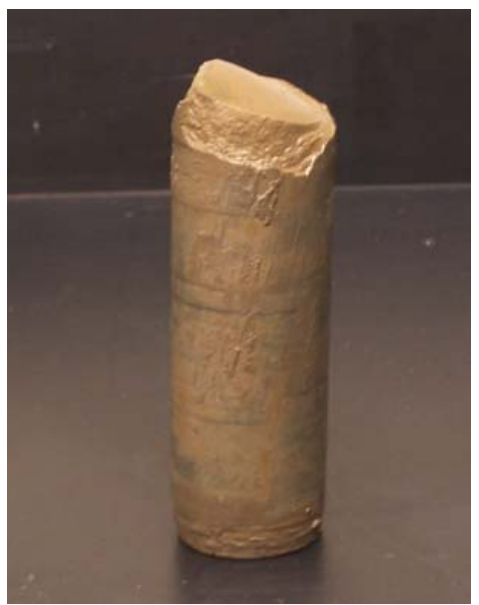

(b)

Figure 3 Cored sample of simulated saltstone (a) bucket of cured simulated saltstone (b) core of simulated saltstone.

\section{Radioactive Samples}

Core samples of saltstone waste in Vault 4 Cell E of the SDF were collected after curing approximately 940 days using a concrete coring bit (Appendix A). Samples were collected from three different locations to a depth of about 20 inches, Figure 4. Location 2 was cored using a "wet" method which used approximately three gallons of water. A dry coring method was used for samples from location 1 and 3 (Smith, 2008 Cheng et.al, 2009). Samples from location 1 were too small for analysis. 


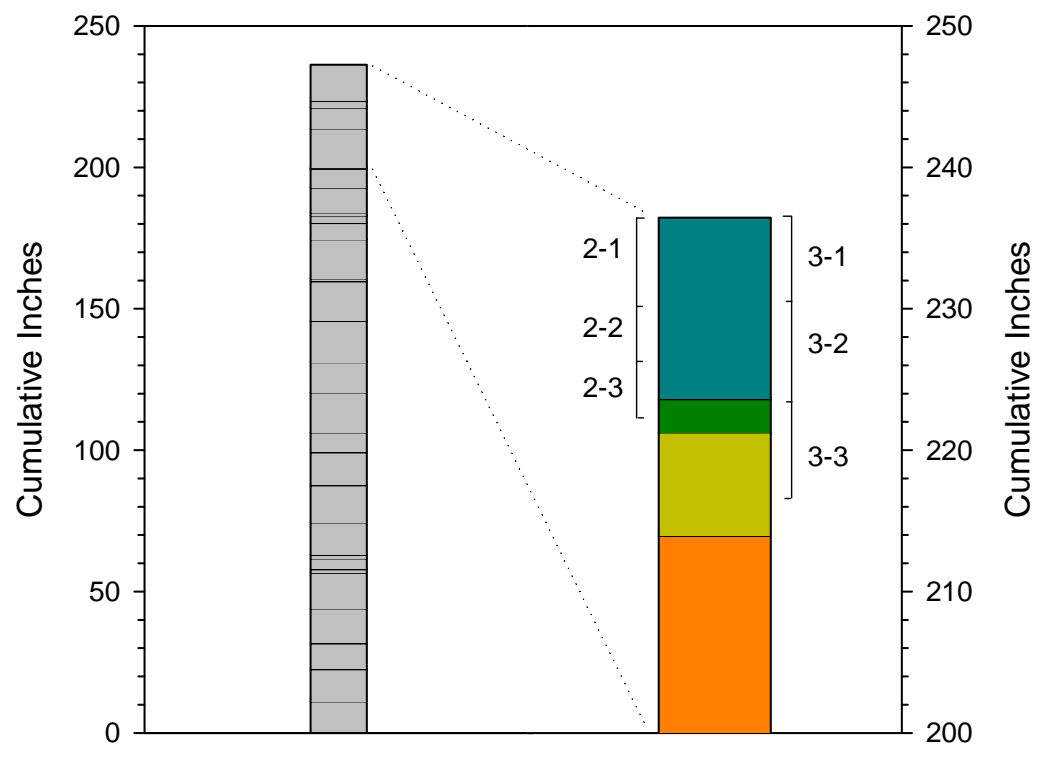

Figure 4 Inventory of saltstone in Vault 4 Cell $\mathrm{E}$

\section{Equipment}

After vacuum saturation, the sample is placed in the tri-axial cell with a glass fiber filter, porous stainless steel (SS) disk, and SS cap on both ends with a surrounding rubber membrane held in place by o-rings, Figure 5 . Back pressure saturation was used to complete the saturation process of saltstone samples to remove residual gas bubbles in pore spaces by compressing and dissolving the trapped gas bubbles into pressurized pore water. The use of high back pressures for saturation requires an external confining pressure to control effective stress on the sample and maintain leak proof contact between the sample and the surrounding membrane. This results in 1-dimensional flow through the sample from head to tail. Back pressure saturation is achieved by placing the sample in a closed chamber, often referred to as tri-axial cell, and applying a confining pressure to the outside of the sample while simultaneously applying back pressure to the sample through end caps. 


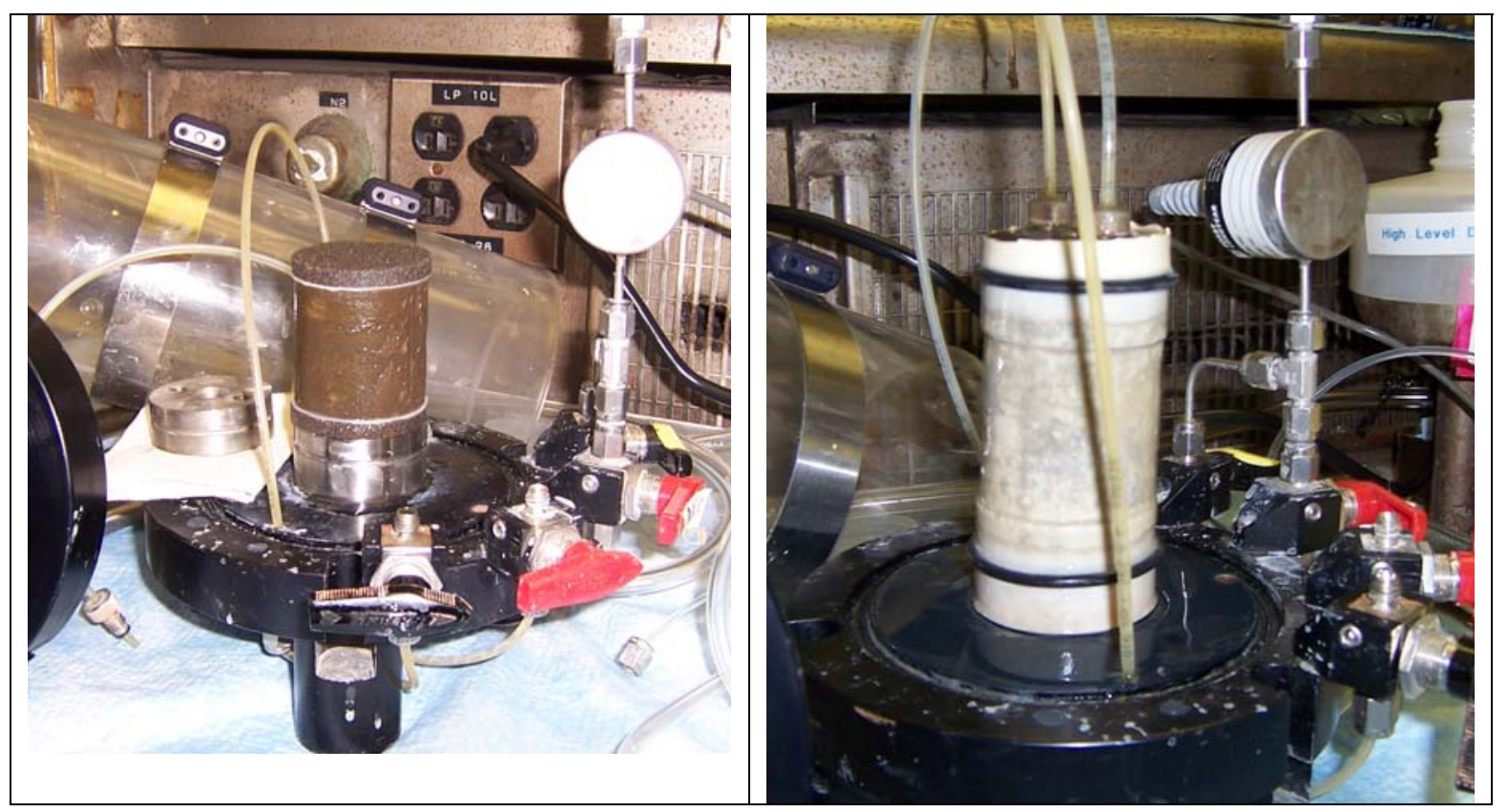

Figure 5 Saltstone sample in flexible wall permeameter.

The FWP and Permeant Interface Devices (PIDs) were placed in a containment hood to minimize the spread of contamination by radioactive pore water in samples from Vault 4. PIDs are placed in the influent and effluent lines between the control panel and FWP to prevent caustic permeant from entering the control panel. A backflow preventer was also used on the FWP to prevent backflow into the permeameter panel located outside the containment hood. 


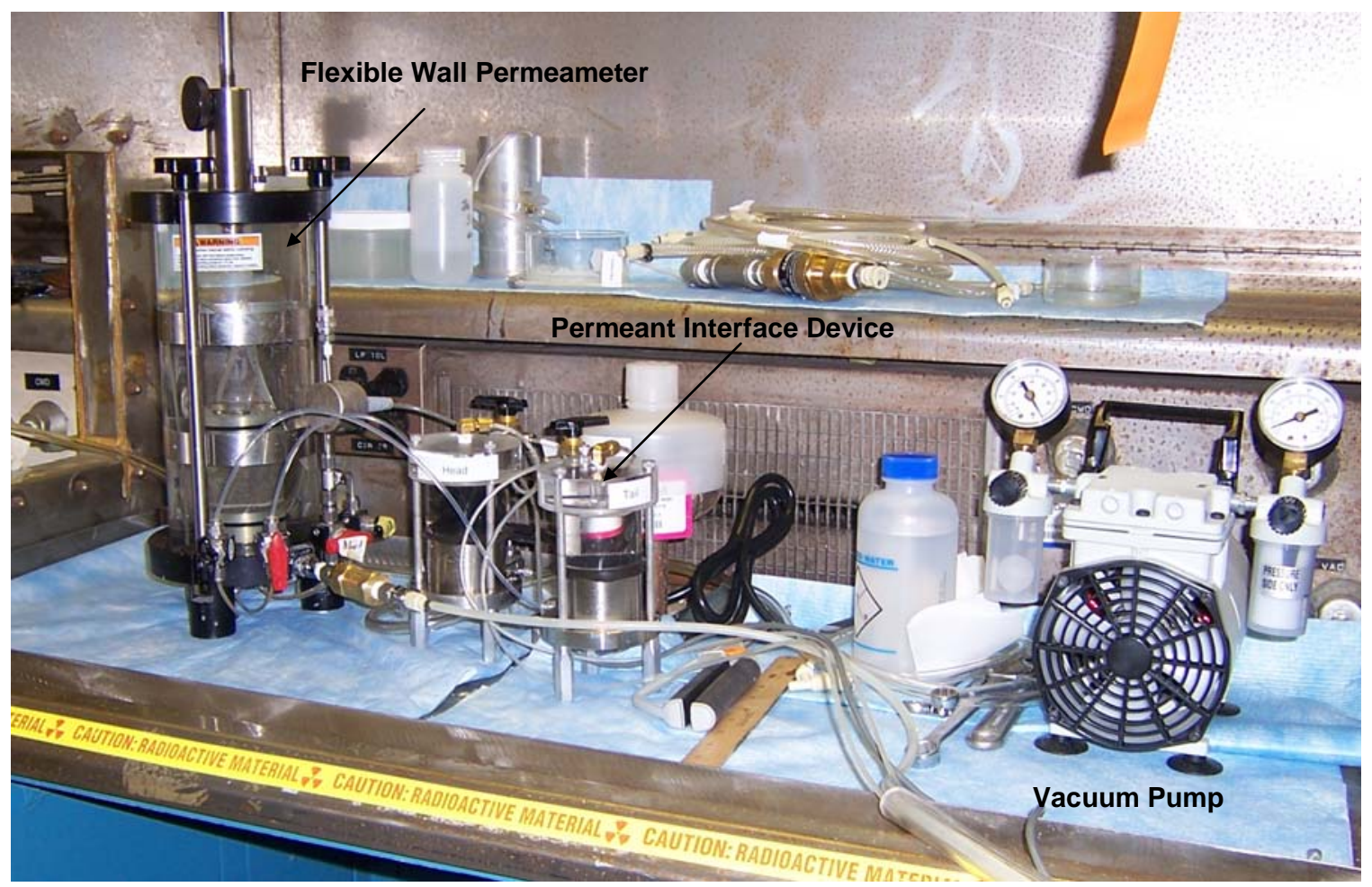

Figure 6 Photo of flexible wall permeameter with permeant interface devices.

Hydraulic conductivity is a function of the pore geometry of a porous material and the fluid flowing through the material. Intrinsic permeability $(k)$ is independent of the fluid properties and is related to $K$ as follows:

$$
K=\frac{\rho g k}{\mu}
$$

$k=$ is intrinsic permeability, $\mathrm{cm}^{2}\left(1 \mathrm{~cm}^{2}=1.01 \times 10^{8}\right.$ darcy $)$

$\mu=$ is dynamic viscosity, (poise, $\mathrm{g} / \mathrm{cm}-\mathrm{s}$ )

$\rho=$ fluid density, $\mathrm{g} / \mathrm{cm}^{3}$

$g$ = gravitational constant, $981 \mathrm{~cm} / \mathrm{s}^{2}$

Therefore, attention must be given when comparing and using $K$ values if different liquids have been used as permeants in FWP testing.

The EPD provided permeant for use in the test. The permeant used in all tests was WCS 11302007 , Table 1 (Cozzi and Duncan, 2009) The WCS permeant has a different specific density and viscosity than water, Table 2 , and as a result the saltstone will have a different hydraulic conductivity for WCS permeant than water. 
Table 1 Chemical composition of WCS 11302007 permeant.

\begin{tabular}{|l|c|}
\hline Constituent & g/L \\
\hline $\mathrm{NaOH}(\mathrm{w} / \mathrm{w} 50.5 \%)$ & 103.3 \\
\hline $\mathrm{NaNO}_{3}$ & 212.3 \\
\hline $\mathrm{NaNO}_{2}$ & 2.19 \\
\hline $\mathrm{Na}_{2} \mathrm{CO}_{3}$ & 5.63 \\
\hline $\mathrm{Na}_{2} \mathrm{C}_{2} \mathrm{O}_{4}$ & 1.01 \\
\hline $\mathrm{Na}_{2} \mathrm{SO}_{4}$ & 0.62 \\
\hline $\mathrm{Al}_{2}\left(\mathrm{NO}_{3}\right)_{3} \cdot 9 \mathrm{H}_{2} \mathrm{O}$ & 45.15 \\
\hline $\mathrm{Na}_{3} \mathrm{PO}_{4} \cdot 12 \mathrm{H}_{2} \mathrm{O}$ & 0.9 \\
\hline $\mathrm{Na}_{2} \mathrm{Al}_{2} \mathrm{O}_{4} \cdot 2 \mathrm{H}_{2} \mathrm{O}$ & 12.71 \\
\hline
\end{tabular}

Table 2 WCS 11302007 permeant properties at $20^{\circ} \mathrm{C}$.

\begin{tabular}{|l|c|c|}
\hline Permeant & Density $\mathbf{( g / \mathbf { c m } ^ { 3 } )}$ & $\begin{array}{c}\text { Dynamic Viscosity } \\
\text { (centipoise) }\end{array}$ \\
\hline Water & 1 & 1 \\
\hline MCU Batch 3\#7 & 1.2267 & 2.2 \\
\hline
\end{tabular}

\section{Results}

Two cored samples of saltstone simulant and seven samples of saltstone core collected from Vault 4 Cell E were tested to determine hydraulic conductivity. A summary of test results for each sample is included in Table 3. Appendix A contains a summary of the test conditions for each of the samples.

\section{Simulant}

\section{Sim V4 Lower}

Sample Sim V4 Lower was saturated under vacuum for six days. Backpressure saturation was conducted for 11 days at increasing pore pressure until a pore pressure of 91 psig was reached. Permeability testing was then performed for seven days. Permeability testing was performed under a confining pressure of 97 psig and with a hydraulic gradient of 29. The effective confining stress (confining pressure - pore pressure) during back pressure testing saturation and FWP testing was five psig. The hydraulic conductivity of sample SIM V4 Lower was determined to be $3.5 \times 10^{-9} \mathrm{~cm} / \mathrm{sec}$, Table 3.

\section{Sim V4 Bottom}

Sample Sim V4 Bottom was saturated under vacuum for seven days. Backpressure saturation was conducted for seven days at increasing pore pressure until a pore pressure of 83 psig was reached. Permeability testing was then performed for six days.

Permeability testing was performed under a confining pressure of 89 psig and with a 
hydraulic gradient of 27. The effective confining stress during back pressure testing saturation and FWP testing was six psig. The hydraulic conductivity of sample SIM V4 Bottom was determined to be $4.4 \times 10^{-9} \mathrm{~cm} / \mathrm{sec}$, Table 3 .

\section{Vault 4 Samples}

Permeability testing was only performed on the portions of the sample what were intact, had no visible fractures or cracks and met the specifications for "undisturbed specimens" identified in Method ASTM D5084-03 Standard Test Methods for Measurement of Hydraulic Conductivity of Saturated Porous Materials Using a Flexible Wall Permeameter that was used for the testing. Two inch long sub-samples were cut from the intact pieces of saltstone core using a hand saw and mitre box. The sub-samples had smooth sides and ends and did not have any visible cracks.

\section{Vault 4 3-3b}

Sample Vault 4 3-3b was saturated under vacuum at 15 inches Hg for 15 days. Backpressure saturation required 11 days at increasing pore pressure until a pore pressure of 83 psig was reached. The effective confining stress during back pressure testing saturation and FWP testing was 11 psig. Permeability testing was performed with a hydraulic gradient of 29. The hydraulic conductivity of sample Vault 43 -3b was determined to be $1.6 \times 10^{-8} \mathrm{~cm} / \mathrm{sec}$. After testing was complete the sample was placed back in a container filled with de-aired permeant for storage.

\section{Vault 4 3-3a}

Sample Vault 4 3-3a was saturated under vacuum at 15 inches Hg for 35 days. Backpressure saturation required eight days at increasing pore pressure until a pore pressure of 87 psig was reached. The effective confining stress during back pressure testing saturation and FWP testing was five psig. Permeability testing was performed with a hydraulic gradient of 14 . The hydraulic conductivity of sample Vault 4 3-3a was determined to be $2.1 \times 10^{-7} \mathrm{~cm} / \mathrm{sec}$. After testing was complete the sample was placed back in a container filled with de-aired permeant for storage.

\section{Vault 4 3-2a}

Sample Vault 4 3-2a was saturated under vacuum at 15 inches Hg for 48 days. Backpressure saturation required seven days at increasing pore pressure until a pore pressure of 40 psig was reached. The effective confining stress during back pressure testing saturation and FWP testing was 4.2 psig. Permeability testing was performed with a hydraulic gradient of 13 . The hydraulic conductivity of sample Vault 43 -2a was determined to be $2.6 \times 10^{-7} \mathrm{~cm} / \mathrm{sec}$.

A second test was conducted at a higher confining pressure of 85 psig to check the results of the test at a confining pressure of 45 psig. Permeability testing was performed with a hydraulic gradient of 17. The hydraulic conductivity of sample Vault 4 3-2a as measured by the second test of 3-2a was determined to be $2.6 \times 10^{-7} \mathrm{~cm} / \mathrm{sec}$. After testing was complete the sample was placed back in a container filled with de-aired permeant for storage. 


\section{Vault 4 3-1a}

Sample Vault 4 3-1a was saturated under vacuum at 16 inches Hg for 41 days. Backpressure saturation required six days at increasing pore pressure until a pore pressure of 71 psig was reached. The effective confining stress during back pressure testing saturation and FWP testing was 3.5 psig. Permeability testing was performed with a hydraulic gradient of 10 . The hydraulic conductivity of sample Vault 43 -1a was determined to be $1.9 \times 10^{-6} \mathrm{~cm} / \mathrm{sec}$. After testing was complete the sample was placed back in container filled with de-aired permeant for storage.

Sample Vault 4 3-1a was re-tested 73 days after the initial test to check reproducibility of the method. Vacuum and backpressure saturation were used to prepare the sample prior to the second test. Backpressure saturation required nine days at increasing pore pressure until a pore pressure of $71 \mathrm{psig}$ was reached. The effective confining stress during back pressure testing saturation and FWP testing was 3.5 psig. Permeability testing was performed with a hydraulic gradient of 10 . The hydraulic conductivity of sample Vault 4 $3-1 \mathrm{a}$ was determined to be $8.8 \times 10^{-7} \mathrm{~cm} / \mathrm{sec}$. After testing was complete, the sample was placed back in a container filled with de-aired permeant for storage.

\section{Vault 4 3-1b}

Sample Vault 4 3-1b was saturated under vacuum at 16 inches Hg for 49 days. Backpressure saturation required 6 days at increasing pore pressure until a pore pressure of 60 psig was reached. The effective confining stress during back pressure testing saturation and FWP testing was 3.5 psig. Permeability testing was performed with a hydraulic gradient of 13 . The hydraulic conductivity of sample Vault $43-1 \mathrm{~b}$ was determined to be $1.5 \times 10^{-7} \mathrm{~cm} / \mathrm{sec}$.

Sample Vault 4 3-1b was tested second time at a higher gradient to check the results of the previous days test at a lower gradient. Permeability testing was performed with a hydraulic gradient of 25. The hydraulic conductivity of sample Vault $43-1 \mathrm{~b}$ as measured by the second test was determined to be $1.4 \times 10^{-7} \mathrm{~cm} / \mathrm{sec}$. After testing was complete the sample was placed back in a container filled with de-aired permeant for storage.

\section{Vault 4 2-1a}

Sample Vault 4 2-1a was saturated under vacuum at 16 inches Hg for 17 days. Backpressure saturation required 11 days at increasing pore pressure until a pore pressure of 82 psig was reached. The effective confining stress during back pressure testing saturation and FWP testing was 2.7 psig. Permeability testing was performed with a hydraulic gradient of 17 . The hydraulic conductivity of sample Vault 4 2-1a was determined to be $1.1 \times 10^{-7} \mathrm{~cm} / \mathrm{sec}$. After testing was complete the sample was placed back in a container filled with de-aired permeant for storage.

\section{Vault 4 2-2a}

Sample Vault 4 2-2a was saturated under vacuum at 16 inches Hg for 29 days. Backpressure saturation required 13 days at increasing pore pressure until a pore pressure of 78 psig was reached. The effective confining stress during back pressure testing saturation and FWP testing was 3.6 psig. Permeability testing was performed with a 
hydraulic gradient of 17 . The hydraulic conductivity of sample Vault 4 2-2a was determined to be $9.9 \times 10^{-8} \mathrm{~cm} / \mathrm{sec}$. After testing was complete the sample was placed back in a container filled with de-aired permeant for storage.

\section{Analysis}

Backpressure saturation was completed on all samples according to guidelines established in ASTM D 5084-03. Simulated saltstone samples cured for 300 days and Vault 4 Cell E saltstone cured $\sim 940$ days before testing. Test results for the dry cored simulant samples cured at $20^{\circ} \mathrm{C}$ are within the range of previously reported results from tests on molded simulated saltstone samples conducted by MACTEC and SRNL, Figure 7. There are not enough tests of cored simulated saltstone to conduct a statistical comparison with molded saltstone samples. Table 3 compares results from tests conducted in this study of cored simulated saltstone samples with cored saltstone waste from Vault 4 Cell E.

All hydraulic conductivity results for Vault 4 samples exceeded results for simulated saltstone samples cured at room temperature, Figure 7 . The average hydraulic conductivity result for Vault 4 Cell E samples of $3.9 \times 10^{-7} \mathrm{~cm} / \mathrm{sec}$ is approximately two orders of magnitude greater than that of the simulated saltstone with an average of $4.1 \mathrm{x}$ $10^{-9} \mathrm{~cm} / \mathrm{sec}$. Numerical flow and transport simulations of moisture movement through saltstone performed for the performance assessment of the saltstone disposal facility used $2.0 \times 10^{-9} \mathrm{~cm} / \mathrm{sec}$ for the hydraulic conductivity of saltstone (Flach et al, 2009).

Results from hydraulic conductivity testing of simulated saltstone samples cured at $60^{\circ} \mathrm{C}$ (Dixon et al, 2009) were comparable to those observed in testing of actual saltstone samples from Vault 4 Cell E (Molded $60^{\circ} \mathrm{C}-\mathrm{SRNL}$, Figure 7). The results for simulated versus actual saltstone were further compared using non-parametric statistics. The nonparametric Wilcoxon rank sum test was chosen due the wide range of results. The statistical test results indicate that there is at least a $98 \%$ probability that the hydraulic conductivity of saltstone samples collected from Vault 4 Cell E saltstone is greater than that of the baseline simulant mix.

Several internal checks of the test method were conducted to evaluate the overall performance of the method. These checks included testing the samples under different pressure gradients and under different effective stresses. In all cases the different test conditions produced nearly the same result for the same sample. Sample Vault 3-1A was re-tested 73 days after its initial test and results were similar which indicates that the method and techniques used for hydraulic conductivity testing used on samples in this report are reproducible.

\section{Conclusions}

Based on the small number of cored simulated saltstone samples submitted for testing the coring method chosen for sample collection does not seem to have a noticeable effect on hydraulic conductivity relative to molded simulated saltstone samples. Permeability results for pieces of in-tact core from Vault 4 Cell $\mathrm{E}$ are similar to results for molded samples of saltstone simulant cured at $60^{\circ} \mathrm{C}$. Factors such as cure temperature and coring 
method for saltstone from Vault 4 Cell E may have caused the permeability results to be higher than those previously reported for saltstone simulant samples prepared in molds.

Table 3 Results from flexible wall permeameter testing of simulated saltstone samples.

\begin{tabular}{|c|c|c|}
\hline Sample Id & $\begin{array}{c}\text { Hydraulic } \\
\text { Conductivity } \\
\text { (cm/sec) }\end{array}$ & $\begin{array}{c}\text { Intrinsic } \\
\text { Permeability } \\
\text { (Darcy) }\end{array}$ \\
\hline $\begin{array}{c}\text { Molded Simulated } \\
\text { Saltstone (a) }\end{array}$ & $\begin{array}{c}8.8 \times 10^{-10} \\
\text { to } \\
9.9 \times 10^{-9}\end{array}$ & $\begin{array}{c}1.8 \times 10^{-6} \\
\text { to } \\
2.0 \times 10^{-5}\end{array}$ \\
\hline Sim Cored V4 Lower & $3.5 \times 10^{-9}$ & $6.5 \times 10^{-6}$ \\
\hline Sim Cored V4 Bottom & $4.4 \times 10^{-9}$ & $8.2 \times 10^{-6}$ \\
\hline Vault 4 Cell E 3-1a & $1.9 \times 10^{-6}$ & $3.5 \times 10^{-3}$ \\
\hline Vault 4 Cell E 3-3b & $1.6 \times 10^{-8}$ & $2.9 \times 10^{-5}$ \\
\hline Vault 4 Cell E 3-3a & $2.1 . \times 10^{-7}$ & $3.9 \times 10^{-4}$ \\
\hline Vault 4 Cell E 3-2a (b) & $2.6 . \times 10^{-7}$ & $4.8 \times 10^{-4}$ \\
\hline Vault 4 Cell E 3-2a (c) & $2.6 \times 10^{-7}$ & $4.7 \times 10^{-4}$ \\
\hline Vault 4 Cell E 3-1b (d) & $1.5 \times 10^{-7}$ & $2.7 \times 10^{-4}$ \\
\hline Vault 4 Cell E 3-1b (e) & $1.4 \times 10^{-7}$ & $2.6 \times 10^{-4}$ \\
\hline Vault 4 Cell E 2-1a & $1.1 \times 10^{-7}$ & $1.9 \times 10^{-4}$ \\
\hline Vault 4 Cell E 2-2a & $9.9 \times 10^{-8}$ & $1.8 \times 10^{-4}$ \\
\hline Vault 4 Cell E 3-1a (f) & $8.8 \times 10^{-7}$ & $1.6 \times 10^{-4}$ \\
\hline
\end{tabular}
(a) Dixon et al, 2009
(b) Pore pressure $=40$ psig
(c) Pore pressure $=85$ psig
(d) Hydraulic gradient $=13$
(e) Hydraulic gradient $=26$
(f) Tested 73 days after initial test of 3-1a 


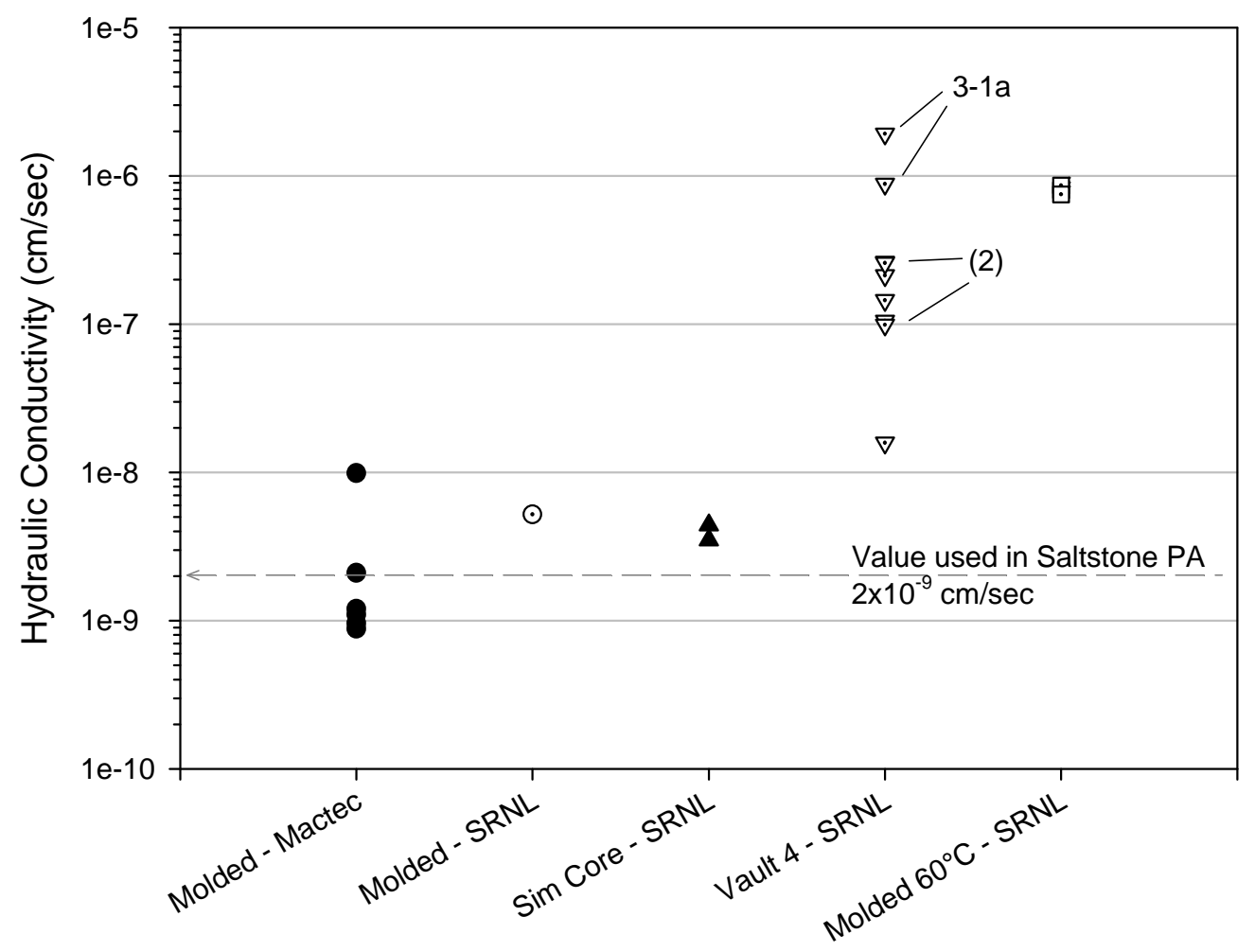

Figure 7 Hydraulic conductivity values for saltstone simulant and Vault 4 Cell samples.

\section{References}

ASTM D 5084-03 Standard Test Methods for Measurement of Hydraulic Conductivity of Saturated Porous Materials Using a Flexible Wall Permeameter Method C, Falling head/rising tailwater elevation.

Cheng, W. Y., A. D. Marzolf, and R. B. Milling, 2009. Recommendations for Improving the Drilled-Core Saltstone Grout Sampling Process, SRNL-STI-2009-00481, Rev. 0. Savannah River Nuclear Solution, LLC.

Cozzi, A. D. and A. J. Duncan, 2009. Characterization of Core Samples Collected from the Saltstone Disposal Facility. SRNL-STI-2009-00804, Rev. 0. Savannah River Nuclear Solution, LLC.

Dixon, K. L., J. R. Harbour, M. A. Phifer, 2009. Hydraulic and Physical Properties of ARP/MCU Saltstone Grout, SRNL-STI-2009-00419 Rev. 0. Savannah River Nuclear Solutions, LLC. 
Flach, G. P., J. M. Jordan, and T. Whiteside, 2009. Numerical Flow and Transport Simulations Supporting the Saltstone Disposal Facility Performance Assessment, SRNLSTI-2009-00115, Rev. 1. Savannah River Nuclear Solutions, LLC.

Hansen, E. K. And A. D. Cozzi. 2009. Task Technical and Quality Assurance Plan for the Vault 4 Saltstone Sample Analysis. SRNL-TR-2009-00005, Rev. 0, Westinghouse Savannah River Company.

Harbour, J. R. 2008. FY09 PA/CA Maintenance Program: Additional Saltstone Property Testing, SRNL L3100-2009-00019, Rev. 0, Savannah River Nuclear Solutions, LLC.

Nichols, R. L. and K. L. Dixon, 2009. Evaluation of Flexible Wall Permeameter in 773-A B110 for Use on Saltstone Samples. SRNS STI-2009-00768, Rev. 0, Savannah River Nuclear Solutions, LLC.

Smith, F. M., 2008. Saltstone Core Sampling Summary for September 2008. LWO-RIP2008-00006, Rev. 0, Savannah River Nuclear Solution, LLC. 
SRNL-STI-2010-00657, Revision 0

Appendix A

Sample and Test Information

Page 18 of 19 


\begin{tabular}{|c|c|c|c|c|c|c|c|}
\hline \multirow[b]{2}{*}{ Sample Id } & \multirow{2}{*}{$\begin{array}{l}\text { Sample } \\
\text { Method }\end{array}$} & \multirow{2}{*}{$\begin{array}{c}\text { Vacuum } \\
\text { Saturation } \\
\text { ("Hg/days) }\end{array}$} & \multicolumn{2}{|c|}{ Test Pressures (psig) } & \multirow[b]{2}{*}{ Gradient } & \multirow{2}{*}{$\begin{array}{c}\text { Cure Time } \\
\text { (days) }\end{array}$} & \multirow[b]{2}{*}{ Laboratory } \\
\hline & & & Confining & Pore & & & \\
\hline TR 551-2 & Molded & $--/ 94$ & 80 & 75.8 & 30 & 249 & SRNL \\
\hline Sim V4 Lower & Core & $--/ 6$ & 97 & 92 & 29 & 283 & SRNL \\
\hline Sim V4 Bottom & Core & $--/ 7$ & 89 & 83 & 27 & 300 & SRNL \\
\hline Vault 4 Cell E 3-1a & Core & $16 / 41$ & 75 & 71 & 10 & $\sim 940$ & SRNL \\
\hline Vault 4 Cell E 3-3b & Core & $15 / 15$ & 94 & 83 & 29 & $\sim 940$ & SRNL \\
\hline Vault 4 Cell E 3-3a & Core & $15 / 35$ & 92 & 87 & 14 & $\sim 940$ & SRNL \\
\hline Vault 4 Cell E 3-2a (a) & Core & $15 / 48$ & 44 & 40 & 13 & $\sim 940$ & SRNL \\
\hline Vault 4 Cell E 3-2a (b) & Core & See above & 85 & 82 & 17 & $\sim 940$ & SRNL \\
\hline Vault 4 Cell E 3-1b (c) & Core & $16 / 49$ & 74 & 70 & 13 & $\sim 940$ & SRNL \\
\hline Vault 4 Cell E 3-1b (d) & Core & See above & 75 & 71 & 25 & $\sim 940$ & SRNL \\
\hline Vault 4 Cell E 2-1a & Core & $16 / 17$ & 85 & 82 & 17 & $\sim 940$ & SRNL \\
\hline Vault 4 Cell E 2-2a & Core & $16 / 29$ & 82 & 78 & 17 & $\sim 940$ & SRNL \\
\hline Vault 4 Cell E 3-1a ${ }^{(\mathrm{e})}$ & Core & 16/-- & 74 & 71 & 10 & $\sim 940$ & SRNL \\
\hline
\end{tabular}

